\title{
MEMFASILITASI ORANG TUA MURID MELALUI KOMUNIKASI VISUAL TENTANG MULTIPLE INTELLIGENCE DI SD ' $X$ ' TANGERANG
}

\author{
Hartini Laswandi ${ }^{1}$ dan Heni Mularsih ${ }^{2}$ \\ ${ }^{1}$ Jurusan Desain, Universitas Tarumanagara Jakarta \\ hartini@fsrd.untar.ac.id \\ ${ }^{2}$ Departemen Psikologi, Universitas Tarumanagara Jakarta \\ henim@mku.untar.ac.id
}

\begin{abstract}
The availability of a facility in the form of infographic or visual communication in a school, there will be a perception and understanding. The purpose of this research is to develop a visual or infographic communication design to provide students with parents' perceptions and understanding, teachers and school users about multiple intelligence. Previous research related to infographics such as the application of color, public service announcements, and the role of infographics as learning media. Methods using an ethnographic approach include examining participants' behavior in certain social situations and also understanding their interpretation of the behavior. Observations, literature studies, and ethnographic interviews were conducted for the data collection process. The data is the basis for designing information designs on posters and ex-banners that are able to provide information about multiple intelligence. The results of this research can provide solutions and benefits, (1) Infographic Design; the school understands that it is necessary to seek information visually about the abilities of students in utilizing multiple intelligence (Multiple Intelligence) that is quite important (2) Implementation of visual /infographic communication design or visual media, can provide information visually clearly. Such as posters, advertisements, leaflets and ex banner printing. In addition, this infographic (posters, leaflets and ex-banner printing) needs to be implemented to provide information services related to the ability of students to use Multiple Intelligence (Multiple Intelligence) for parents.
\end{abstract}

Keywords: Facilities; Visual Communication; infographics; Multiple Intelligence

\begin{abstract}
ABSTRAK
Ketersediaan suatu fasilitas yang berupa infografis atau komunikasi visual di suatu sekolah, maka akan terjadi persepsi dan pemahaman. Tujuan dari penelitian adalah mengembangkan desain komunikasi visual atau infografis untuk memberikan persepsi dan pemehaman kepada orang tua murid, guru dan pengguna sekolah tentang kecerdasan majemuk (Multiple Intelligence). Penelitian sebelumnya terkait infografis seperti penerapan warna, iklan layanan masyarakat, dan peran infografis sebagai media pembelajaran. Metode dengan menggunakan pendekatan etnografi mencakup pemeriksaan perilaku peserta dalam situasi sosial tertentu dan juga memahami interpretasi mereka terhadap perilaku tersebut. Observasi, studi literatur, dan wawancara etnografi dilakukan untuk proses pengumpulan data. Data tersebut menjadi dasar dalam perancangan desain informasi pada poster dan ex-banner yang mampu memberikan informasi tentang kecerdasan majemuk (Multiple Intelligence). Hasil penelitian ini dapat memberikan solusi dan manfaat, yaitu (1) Desain Infografis; pihak sekolah paham bahwa perlu untuk mengupayakan informasi secara visual tentang kemampuan yang dimiliki peserta didik dalam memanfaatkan Inteligensi ganda (Multiple Intelligence) itu merupakan hal yang cukup penting (2) Implementasi Desain komunikasi visual/infografis atau media visual, dapat memberikan informasi secara visual dengan jelas. Seperti poster, iklan, leaflet dan ex banner printing. Selain itu perlu diimplementasikan infografis ini (poster, leaflet dan ex-banner printing) untuk memberikan layanan informasi yang berkaitan dengan kemampuan yang dimiliki peserta didik dalam memanfaatkan Inteligensi ganda (Multiple Intelligence) pada orang tua.
\end{abstract}

Kata Kunci: Fasilitas; Komunikasi Visual; infografis; Multiple Intelligence 


\section{PENDAHULUAN}

Selama ini orang tua menilai kecerdasan yang dimiliki anaknya terlalu sempit, mereka menganggap anak hanya memiliki satu kecerdasan yang dapat diukur yaitu kecerdasan logikamatematika, sedangkan alat yang digunakan untuk mengukur kecerdasan tersebut adalah tes IQ. Kecerdasan siswa yang terlihat pada prestasi akademik kadang akan menghasilkan generasi muda yang kurang berinisiatif seperti menunggu instruksi, takut salah, malu mendahului yang lain, hanya ikut-ikutan, salah tetapi masih berani bicara (tidak bertanggung jawab), mudah bingung karena kurang memiliki percaya diri, serta tidak peka terhadap lingkungannya. Di samping itu siswa demikian akan memiliki sifat-sifat yang tidak sabar, ingin cepat berhasil walaupun melalui jalan pintas, kurang menghargai proses, mudah marah sehingga banyak menimbulkan kerusuhan dan tawuran. Kecerdasan logika atau intelegensi hanya terbatas pada aspek kognitif, atau yang sering disebut IQ.

Seharusnya Peserta didik dapat mengoptimalkan potensi yang ada pada dirinya, sehingga, peserta didik mampu mengaktualisasikan diri dan menyelaraskan potensi dengan kecerdasan majemuk (Multiple Intelligence) yang dimiliki peserta didik. Hendaknya peserta didik mulai mempersiapkan karir sejak dini. Sehingga peserta didik lebih optimal untuk mengeksplorasi karir nantinya. Peserta didik harus memiliki sejumlah informasi yang memadai yang berhubungan dengan bakatnya. Peserta didik membutuhkan bantuan bimbingan dari guru BK dan orang tuanya untuk memperoleh pengarahan, pengetahuan dan pemahaman yang memadai tentang berbagai kondisi dan karakteristik diri. Pembekalan informasi mengenai keadaan diri, bakat dan informasi mengenai prospek potensi diri akan mengurangi kesalahan peserta didik dalam pemilihan studi lanjut untuk masa depan.

Permasalahan yang terjadi di kalangan SDIT Yasir di Tangerang adalah tidak ketersediaannya layanan informasi visual bagi orang tua murid dan siswa di sekolah. Hal tersebut ditunjukkan dengan perilaku kebingungan dalam mengarahkan bakat anak, banyaknya anggapan dari orang tua murid jika anaknya memiliki kecerdasan intelektual rendah/IQ rendah maka kurang memiliki kecerdasan.

Berdasarkan permasalahan tersebut di atas, maka diperlukan pemberian layanan informasi yang berkaitan dengan kemampuan yang dimiliki peserta didik dalam memanfaatkan Inteligensi ganda (Multiple Intelligence) pada orang tua dan peserta didik di SDIT Yasir Tangerang. Optimalisasi publikasi layanan informasi ini berbasis pada informasi dan komunikasi visual yang dilakukan untuk mendukung pengembangan pemanfaatan Inteligensi ganda (Multiple Intelligence). Hal ini sebagai bentuk perwujudan keterbukaan informasi public/orang tua murid yang dilakukan di SDIT Yasir Tangerang. Iklan layanan informasi/komunikasi visual digunakan untuk menyampaikan informasi, mempersuasi khalayak untuk orientasi fungsi sosial bukan semata orientasi ekonomi seperti layaknya iklan komersial. Keuntungan sosial yang dimaksud adalah munculnya pengetahuan, kesadaran sikap, perubahan perilaku otang tua murid terhadap pengembangan pemanfaatan Inteligensi ganda (Multiple Intelligence).

Dengan demikian, tujuan penelitian ini ingin memfasilitasi agar dapat memberikan layanan informasi yang berkaitan dengan kemampuan yang dimiliki peserta didik dalam memanfaatkan Inteligensi ganda (Multiple Intelligence). Penelitian pengembangan desain infografis untuk memberikan persepsi dan pemehaman kepada orang tua murid, guru dan pengguna sekolah tentang kecerdasan majemuk (Multiple Intelligence). Layanan informasi visual di sekolah adalah layanan pemahaman yang berupa informasi secara visual bagi orang tua murid, siswa, guru dan pihakpihak lain untuk menerima dan memahami informasi dalam mempertimbangkan pengambilan 
keputusan. Layanan informasi di sekolah membantu siswa untuk membuat keputusan yang bebas dan bijaksana terutama tentang kemampuannya dan pilihannya. Infografis merupakan salah satu pilihan masyarakat atau organisasi sebagai media publikasi informasi. Menurut Jasson Lankow (2015) dalam bukunya Infografis: Kedahsyatan Cara Bercerita Visual, mengatakan keunggulan komunikasi visual melalui infografis antara lain: visualisasi gambar mampu menggantikan penjelasan yang terlalu panjang. Melalui visualisasi grafis data yang menarik, pesan-pesan kebijakan yang ingin disampaikan diharapkan lebih mudah mendapat perhatian dari publik (Lankow, 2015). Mengacu hasil penelitian terdahulu bahwa seseorang cepat menangkap informasi yang tersaji dalam bentuk visual (grafis) daripada dalam bentuk tekstual.

Informasi fisual/infografis dapat memberikan pemahaman kepada pengguna sekolah, yaitu berupa fakta, konsep, dan prinsip tertentu. Proses memahami menurut (Asmuniv, 2015) yaitu: (1) menginterpretasikan atau menafsirkan; (2) memberikan contoh; (3) mengklasifikasikan; (4) merangkum; (5) menyimpulkan; (6) membandingkan; (7) menjelaskan. Infografis merupakan satu media penyampai informasi yang mengedepankan aspek kreatif visual. Infografis (Taufik, 2012). Kegunaan Infografis di sekolah dalam penyampaian Informasi kepada guru, siswa dan orang tua murid mengenai pemahaman dan keterlibatan dalam proses pembelajaran. Dengan demikian infografis seharusnya juga menjadi salah satu desain aplikasi visual yang mampu diterima dan diterapkan oleh siswa maupun guru di sekolah. Taufik (2012). Infografis merupakan bagian dari ilmu komunikasi visual, sebagai kajian dalam bentuk informasi grafis yang mana lebih banyak dipakai kebutuhan aplikasinya pada berbagai permasalahan dalam bidang pendidikan, kedokteran, dirgantara, ekonomi, sejarah, olahraga, politik dan seterusnya. Infografis banyak menjadi inspirasi untuk menjelaskan suatu data yang panjang menjadi bahasa penyampaian yang sangat pendek tapi sangat jelas. Secara garis besar ada empat jenis infografis menurut Artacho (Artacho-Ramírez, 2008), yaitu : (a) Infografis yang berdasarkan pada statistik (statistical based) yaitu infografis yang berdasarkan pada statistik mencakup diagram, bagan, grafis, tabel dan daftar. (b) Infografis yang berdasarkan pada jadwal (timeline based) yaitu infografis yang berdasarkan pada jadwal menunjukkan urutan kejadian dari waktu ke waktu dan juga memungkinkan audien memahami hubungan kronologis secara cepat. (c) Infografis yang berdasarkan pada proses (process based) atau dapat dipergunakan juga untuk menjelaskan tentang sekolah, ruang kerja, pabrik atau kantor sehingga pembaca memahami informasi secara praktis. (d) Infografis yang berdasarkan pada lokasi atau geografi. Dengan mempergunakan geographic information system, peta dapat dipertimbangkan sebagai cara terbaik untuk menunjukan infografis berdasarkan geografi.

\section{METODE PENELITIAN}

Metode menggunakan deskriptif kualitatif dengan pendekatan etnografi yang berangkat dari masalah pada SDIT Yasir Tangerang tentang pengetahuan Multiple Intelligece/kecerdasan majemuk yang tidak dimiliki orang tua murid. Penelitian ini mencakup dua tahap, yaitu tahapan penelitian dan perancangan.

Tahapan penelitian mencakup proses pengumpulan data hingga analisis data. Pengumpulan data dalam penelitian ini dilakukan dengan studi literatur, observasi dan wawancara etnografi dengan narasumber. Narasumber terdiri atas desainer senior infografi dan desainer font. Hasil pengumpulan data kemudian dianalisis untuk dijadikan dasar acuan dalam proses perancangan. Data terkait Multiple Inteligent/kecerdasan majemuk yang dihasilkan, dianalisis sesuai dengan teori tipografi sehingga didapatkan elemen-elemen dalam ex-banner dan poster.

Tahapan perancangan desain informasi Multiple Inteligent/kecerdasan majemuk dimulai dengan merancang mind-mapping dan pembuatan sketsa ex-banner dan poster sebagai media terpilih. 
Kemudian dilakukan perancangan ex-banner dan poster yang terdiri pemahaman tentang Multiple Inteligentl kecerdasan majemuk, profesi yang sesuai, dan bagaimana mengoptimalkan keceedasann yang dimiliki oleh anak. Seluruh sistem desain grafis dalam ex-banner dan poster dirancang dengan memunculkan nilai khas visual dengan sentuhan masa kini yang menarik.

\section{HASIL DAN PEMBAHASAN}

\subsection{Desain Komunikasi Visual atau Infografis}

Konten dalam poster dan ex-banner infografis tersusun dari materi kecerdasan majemuk/multiple intelligece, profesi yang mendukung di setiap potensi kecerdasan, dan ajakan kepada semua pihak untuk memahami kecerdasan majemuk pada anak. Poster dan ex-banner infografis disajikan dengan warna yang cerah untuk menarik perhatian dan memberi efek semangat, kata dipilih dengan ukuran yang besar dan jelas, logo institusi penyelenggara, penjelasan sekilas tentang jenisjenis kecerdasan, serta kartun siswa yang menarik menggambarkan obyek yang dituju. Komponen desain poster dapat dilihat pada Gambar 1, 2, 3, 4. Gambar 5 merupakan hasil desain poster dan ex-banner yang telah terkonsep dan siap produksi.
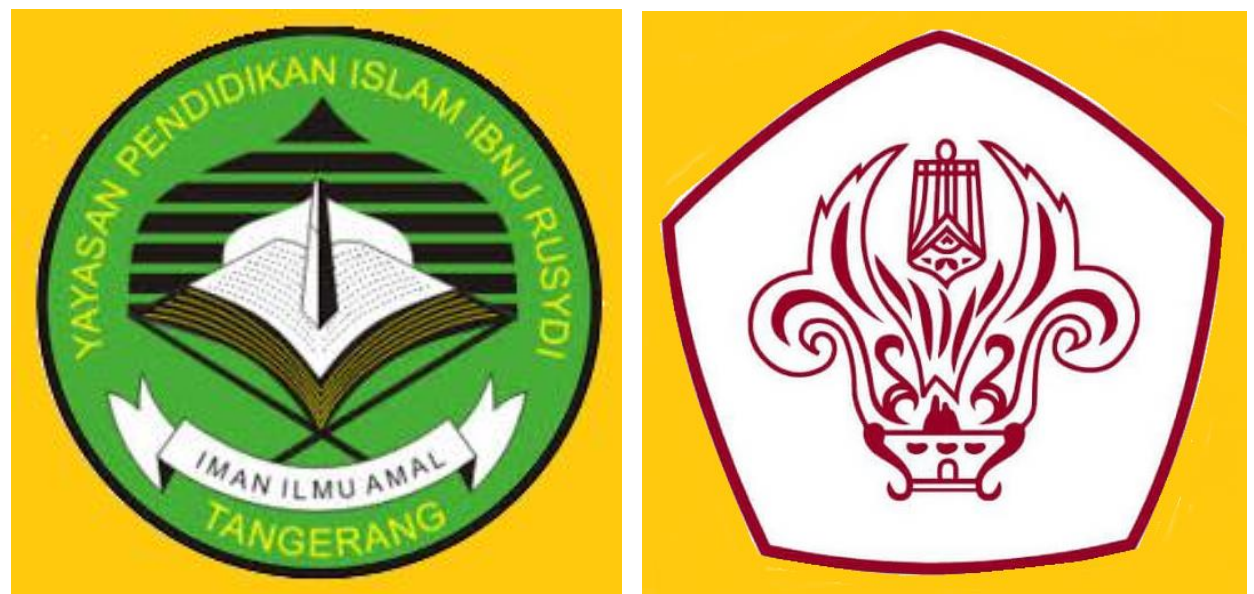

Gambar 1 : Komponen poster infografis terdapat Logo institusi pendukung
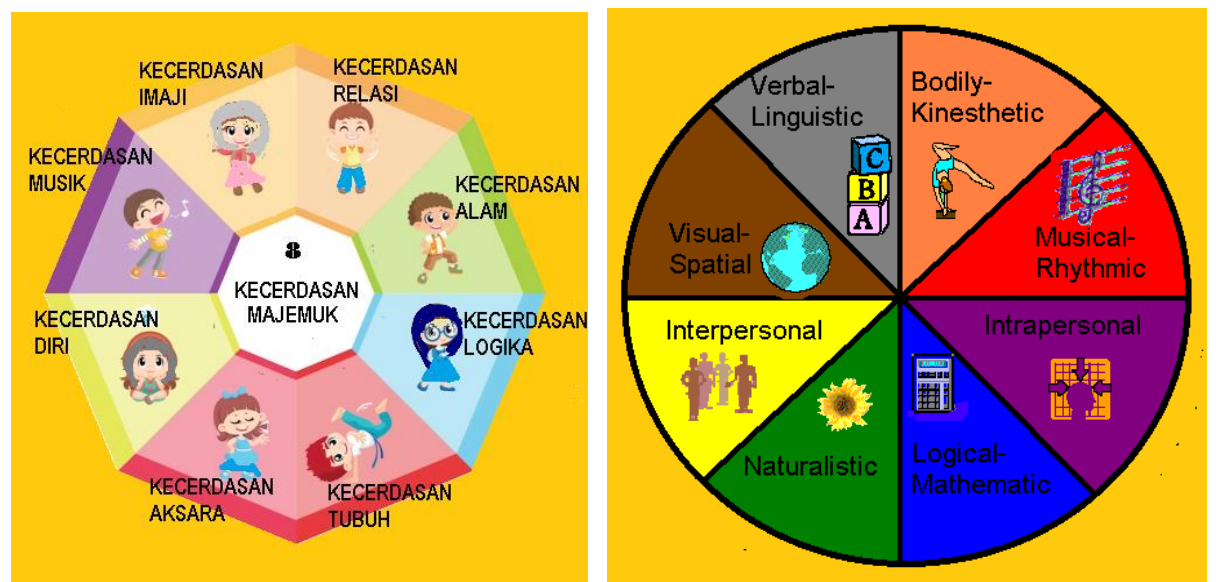

Gambar 2 : Komponen poster infografis terdapat materi yang disampaikan; jenis-jenis kecerdasan majemuk/multiple intelligence 

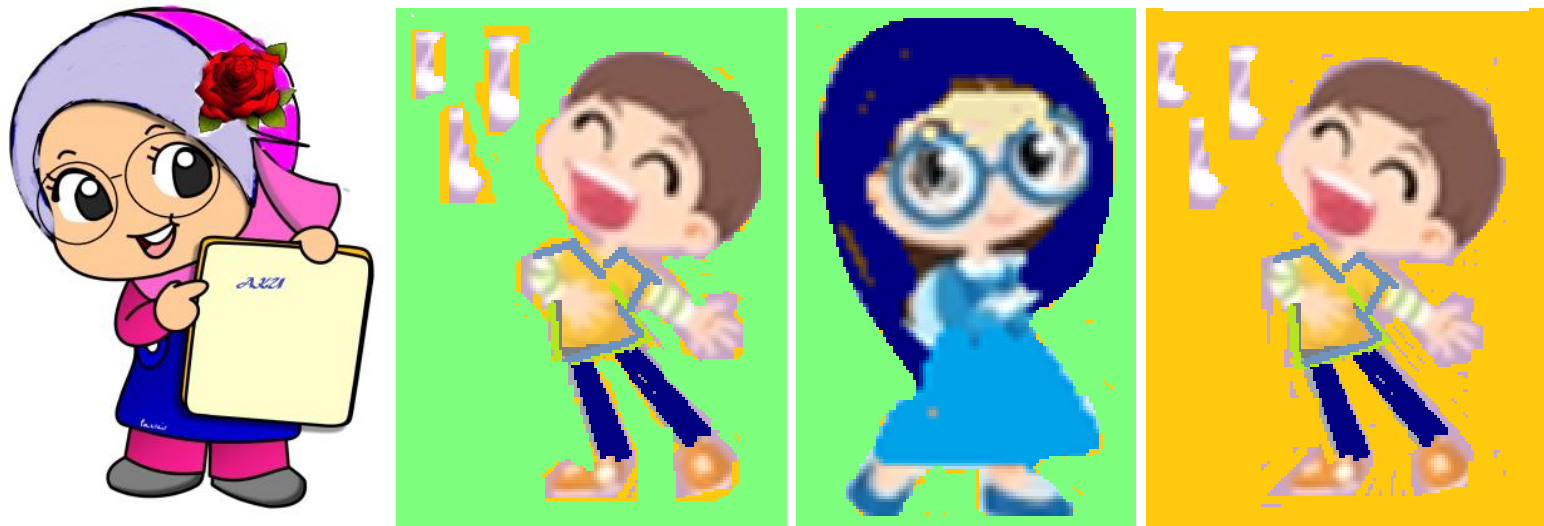

Gambar 3 : Komponen poster infografis terdapat kartun siswa untuk menarik pembaca, Dan menggambarkan obyek yang dituju.

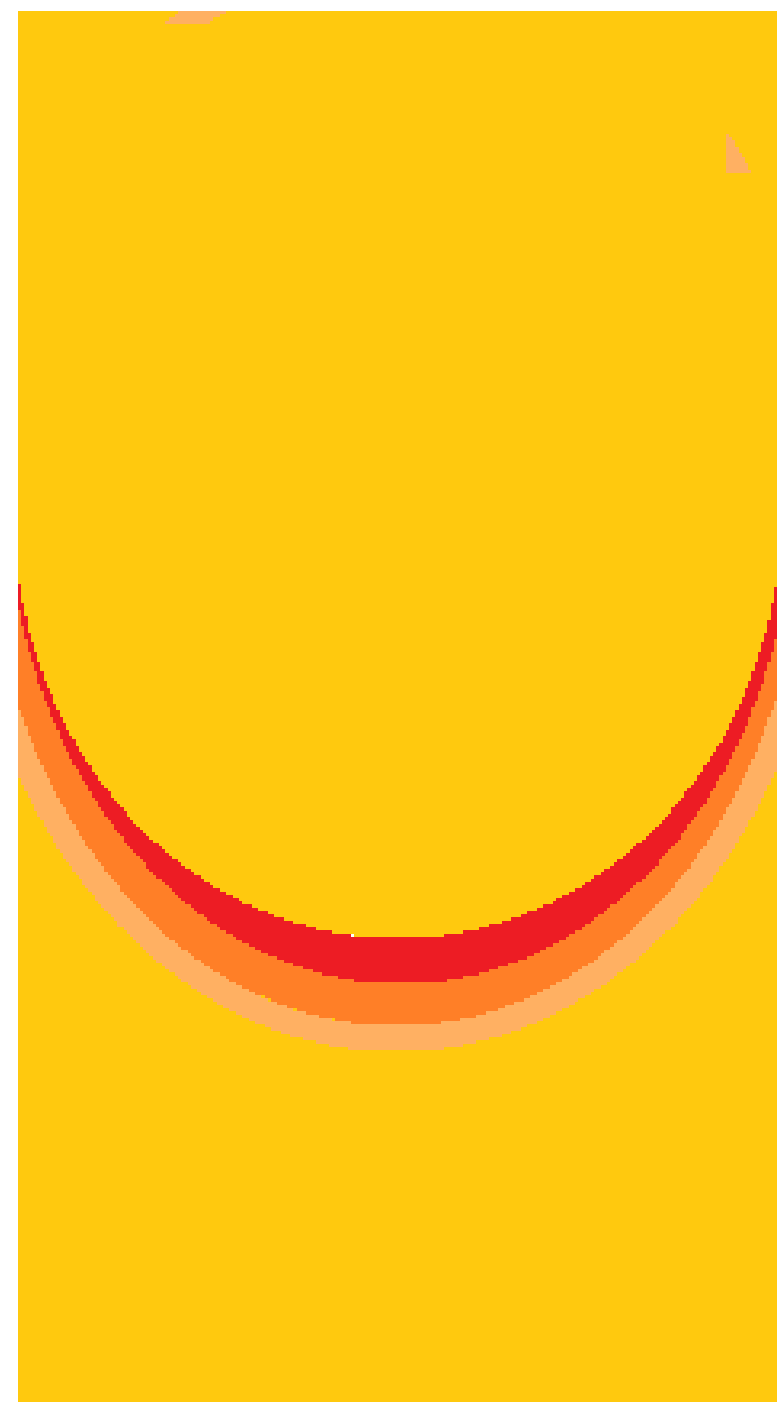

Gambar 4 : Komponen baground poster infografis warna yang cerah untuk menarik pembaca dan memberi efek semangat 


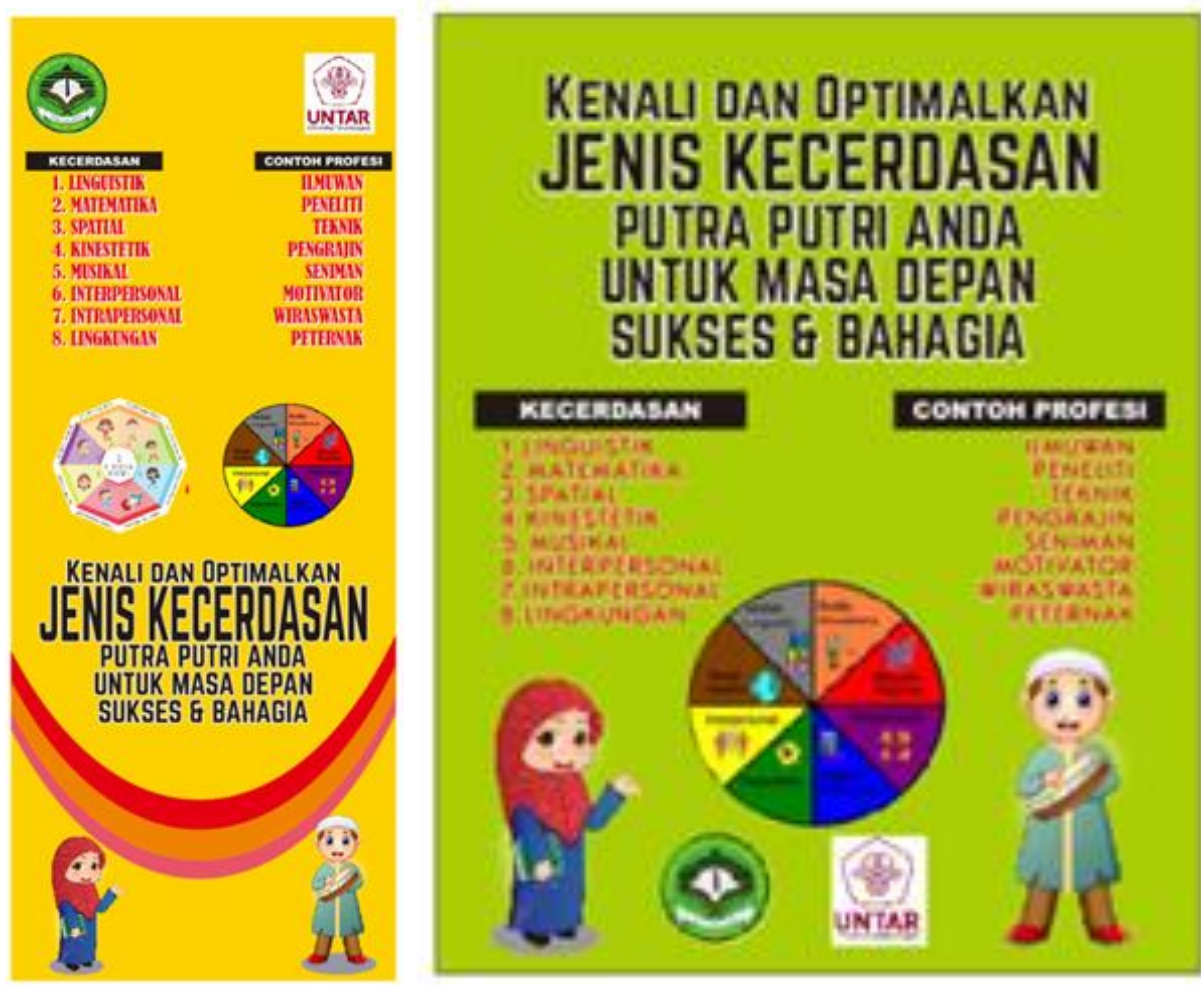

Gambar 5 : Desain poster infografis berupa ex-banner dan poster tentang kecerdasan majemuk/multiple intelligence

\subsection{Implementasi Desain Komunikasi Visual atau Infografis}

Poster dan ex-banner printing tentang informasi kemampuan yang dimiliki peserta didik dalam memanfaatkan Inteligensi ganda (Multiple Intelligence), diimplementasikan pada area yang mudah dibaca oleh pengunjung. Implementasi poster dan ex-banner ditempatkan pada :

- Ruang tunggu: poster frame

- Ruang kepala sekolah dan ruang guru: ex-banner dan poster frame

- Ruang serba guna: poster frame, ex-banner dan leaflet

Implementasi poster dan ex-banner dapat dilihat pada Gambar 6 dan Gambar 7.
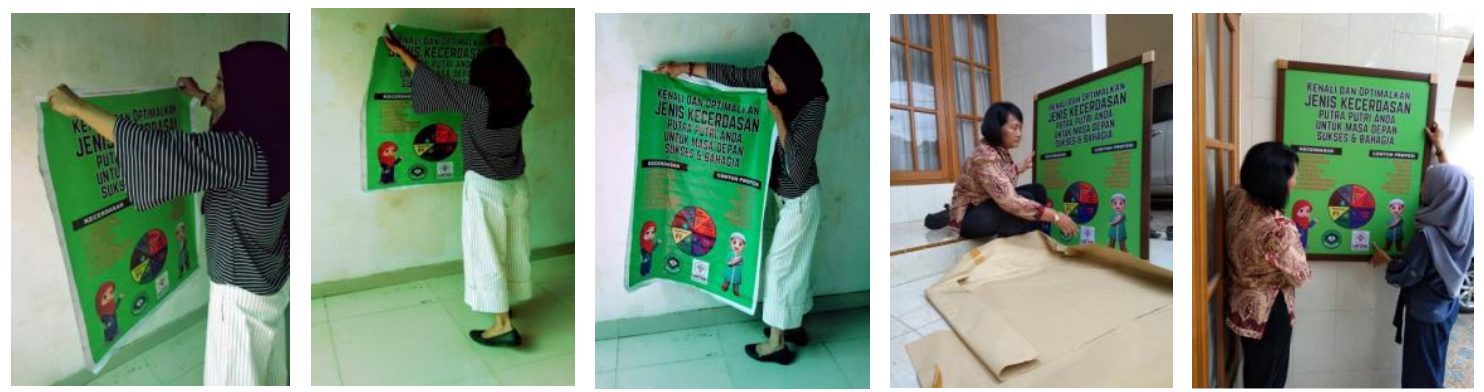

Gambar 6 : Hasil Desain Infografi Berupa Poster Diimplementasikan di Area Tunggu Sekolah

Infografis diimplementasikan pada area tunggu dengan hasil analisis sbb :

a. Area tunggu merupakan area publik yang biasa digunakan oleh orang tua murid saat menunggu putra putrinya saat menjemput pulang sekolah.

b. Area tunggu juga digunakan oleh tamu sekolah yang datang untuk urusan tertentu. 

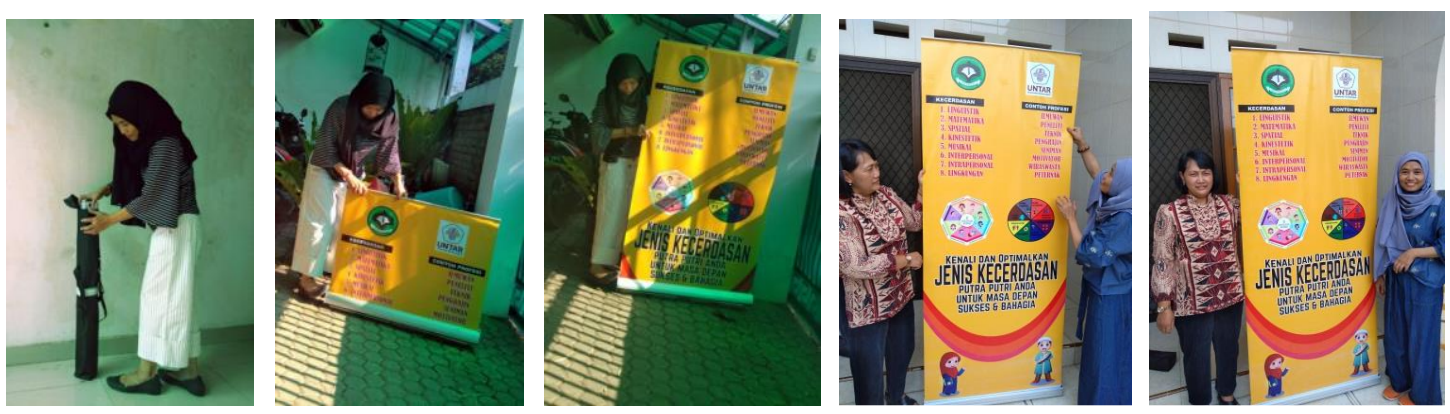

Gambar 7 : Hasil Desain Infografi Berupa Ex-Banner Diimplementasikan di Area Tunggu Sekolah dan Depan Ruang Guru

Infografis diimplementasikan pada area guru dan area tunggu dengan hasil analisis sbb :

a. Area depan ruang guru merupakan area semi privat yang biasa digunakan oleh guru setelah beraktifitas mengajar, area guru juga sering dikunjungi orang tua murid saat ada kepentingan terkait putra putrinya dalam pembelajaran sekolah.

b. Area tunggu dan area guru juga digunakan atau dikunjungi oleh tamu sekolah yang datang untuk urusan tertentu.

\section{KESIMPULAN DAN SARAN}

Pentingnya memfasilitasi infografi secara visual untuk orang tua murid, yang berisi informasi terkait kemampuan yang dimiliki peserta didik dalam memanfaatkan Inteligensi ganda (Multiple Intelligence). Spesifikasi luaran kegiatan berupa pemberian peningkatan pemahaman informasi tentang Inteligensi ganda (Multiple Intelligence). Pihak sekolah memperoleh hasil Desain komunikasi visual/infografis atau media visual, yang dapat dilihat dan memberikan layanan informasi audience dengan jelas. Pihak sekolah memperoleh hasil desain infografis berupa poster frame, leaflet dan ex-banner. Luaran yang dicapai target pertama: pengelola sekolah memahami pentingnya memberikan pemahaman tentang kemampuan yang dimiliki peserta didik dalam memanfaatkan Inteligensi ganda (Multiple Intelligence). Target kedua: membuat hasil desain infografis atau desain komunikasi visual. Layout desain komunikasi visual ini diimplementasikan dipasang pada dinding, depan ruangan, dan selebaran bagi para guru. Target Ketiga: Implementasi infografis (poster, leaflet dan ex-banner printing) untuk memberikan layanan informasi yang berkaitan dengan kemampuan yang dimiliki peserta didik dalam memanfaatkan Inteligensi ganda (Multiple Intelligence) pada orang tua.

\section{Ucapan Terima Kasih (Acknowledgement)}

Terima kasih kepada LPPM UNTAR yang telah memberikan fasilitas dan dukungan dana pada kegiatan PKM, sehingga kegiatan ini berlangsung baik dan lancar.

\section{REFERENSI}

Ariefika Listya. (2019), Konsep Dan Pengunaan Warna Dalam Infografis. Program Studi Desain Komunikasi Visual, Fakultas Bahasa Dan Seni Universitas Indraprasta Pgri, Jurnal Desain, ISSN 2339-0109

Agus Setiawan, (2015), Strategi Kreatif Iklan Layanan Masyarakat (Tinjauan Perancangan Ilm Karya Mahasiswa Dkv Udinus) February 2015. Program Studi Desain Komunikasi Visual Fakultas Ilmu Komputer, Universitas Dian Nuswantoro Semarang. Https://Www.Researchgate.Net/Publication/311303850 
Aditiya K, Arief AS, Jacky C (2019), Perancangan Video Infografis Mengenai Dampak Sampah Plastik Bagi Hewan Laut. Program Studi Desain Komunikasi Visual, Fakultas Seni Dan Desain, Universitas Kristen Petra, Surabaya. Jurnal DKV Adiwarna. Vol 1, No 14

Artacho-Ramírez, M Diego-Mas, J., \& Alcaide-Marzal, J. (2008). Influence of the mode of graphical representation on the perception of product aesthetic and emotional features: An exploratory study. International Journal of Industrial Ergonomics, 942-952.

Fakhruddin D, Sachari A, Haswanto N (2018), Pengembangan Desain Informasi Dan Pembelajaran Aksara Jawa Melalui Media Digital Interaktif, FSRD ITB Bandung. JADECS, Vol 3, No 2 (2018)

Lankow, J., Ritchie, J., Crooks, R. (2015). Infografis: Kedasyatan cara bercerita visual. Jakarta: Gramedia Pustaka Utama.

Mukaromah,Yanuarsar DH, Mutia RP, (2017), Iklan Layanan Masyarakat Dan Respon Khalayak Program Studi Ilmu Komunikasi, Program Studi Desain Komunikasi Visual Fakultas Ilmu Komputer, Universitas Dian Nuswantoro Semarang. Islamic Comunication Journal Vol 02, Nomor 02, Juli-Desember 2017

Taufik, M. (2012). Infografis Sebagai Bahasa Visual Pada Surat Kaar Tempo. Techno CQM, 156-163.

Taufiq HA, Musadad AA, Susanto (2019), Infografis Sebagai Media Alternatif Dalam Pembelajaran Sejarah Bagi Siswa SMA, Universitas Sebelas Maret, Surakarta, Andharupa: Jurnal Desain Komunikasi Visual \& Multimedia

Wulandari MV, Zainul A, Henry P (2019) Pengembangan Media Pembelajaran E-Book Infografis Sebagai Penguatan Kognitif Siswa X. Jurusan Teknologi Pendidikan, Fakultas Ilmu Pendidikan, Universitas Negeri Malang, JKTP Jurnal Kajian Teknologi Pendidikan JKTP Vol 2 No (1) Februari (2019):37-44 http://journal2.um.ac.id/index.php/jktp/index 